\title{
IMPROVING THE QUALITY OF TEACHERS' TEACHING ADMINISRASTION PLANS THROUGH ACADEMIC SUPERVISING AT SMA IN KABUPATEN ROKAN HULU, RIAU PROVINCE
}

\author{
Parman Hasibuan
}

\author{
Dinas Pendidikan Provinsi Riau
}

\begin{abstract}
ABTRACT
The research was aimed at improving the teachers' competence in managing their teaching administration effectively. At the beginning, it was found that majority of English teachers in SMA did not have complete the components of teaching Administration as suggested by the educational ministry regulation number 41/2007 in Kurikulum Tingkat Satuan Pendidikan (KTSP). It was because almost all English teachers did not know what they should prepare for their administration fulfillment. The research is a case study. The data collection of the study was gained through the activities of pre-observation, field notes, real observation, colleague coaching or training, and documentation. Those data were then analyzed using table of scores in the professional competence instrument. The steps taken to overcome the teachers' teaching administration problems are among others by doing some strategies of coaching, guiding, discussing and socializing the standardized process of Indonesian National Standard of Education to English teachers. As a result of the study, from almost zero to hero, the teachers' understanding and competences about teaching administration fulfillment raised, ranging from $29 \%$ to $87 \%$ (at the beginning to the end of the study). School supervisors are recommended to do similar research activities to prove the truth of the findings. For teachers, particularly English teachers, it is suggested that they change their mind set in managing their jobs. Finally, it is expected that this study will have good contribution to enhance the English teachers' competences in managing their jobs.
\end{abstract}

Key words: improvement, academic supervising, teachers' teaching administrations, observation, coaching 


\section{INTRODUCTION}

Many people thought that the position of being supervisors in Indonesia was a disposal one or unnecessary position. The writer, however, believes it is not really true. In fact, it is a grace from the almighty God. One proof which the writer felt thankful to God was the fact that this position was really needed by teachers at schools. Some teachers said, . Frankly

speaking, at first the writer felt unstable because of the writer's shortage of experience in teaching and managing school. In July 2011, the writer was once assigned by the head of Rokan Hulu regency office of education, youth, and sports to be duty headmaster at SMA Negeri 2 Rambah Hilir. It lasted only for two months before the writer was posted as the headmaster at SMP Negeri 3 Rambah on September $7^{\text {th }}, 2011$ by the regency head of education, youth, and sport office. It lasted only for 4 months and 11 days. The head of Rokan Hulu regency office of education, youth, and sports again posted the writer as a supervisor for senior high school English teachers, exactly on $18^{\text {th }}$ of January 2012. A three-change of position happened in a short time, ranging from July 2011 to January 2012.

In the running of tasks as supervisor, the writer believed that having high curiosity was a good capital for overcoming problems in running the jobs as supervisor. One of the problems the writer felt successful to overcome was about teachers' problems in administrating their tasks and teaching plans. It was the fact that majority of the teachers as the writer's coached members were not good at administering their teaching activities and plan. It was due to the absence of knowledge about administration components needed by a teacher. This indication was one of the causes of teachers' failure to plan their future actions and find the solutions to problems they had confronted previously. They did not have the minimal standard administration as suggested by Kurikulum Tingkat Satuan Pendidikan (KTSP). This problem made the writer feel uneasy. The writer was curious about how to overcome the problems. Through pre-observation, the writer tried to collect real data from the teachers. Using a pre-supervision instrument, the writer collected data. The data showed that from 20 English teachers, no one had a complete teaching administration yet. It means that $100 \%$ English teachers did not administer their teaching and plan activities well as required in KTSP. 
Schedule of Study Activities

\begin{tabular}{|l|l|l|l|}
\hline No & $\begin{array}{c}\text { Months, } \\
\text { Dates }\end{array}$ & \multicolumn{1}{|c|}{ Description of Activities } & Notes \\
\hline 1 & $\begin{array}{l}\text { February } \\
10\end{array}$ & Supervision: Pre-observation & \\
\hline 2 & $\begin{array}{l}\text { February } \\
17\end{array}$ & $\begin{array}{l}\text { Zeroxing and distribution: Regulation and teachers' } \\
\text { documents }\end{array}$ & \\
\hline 3 & March 10 & Gathering coached teachers: Meeting & \\
\hline 4 & April 7-28 & School visits: follow up meeting & \\
\hline 5 & May 5 & Data analyses & \\
\hline 6 & June 5 & Study Report & \\
\hline
\end{tabular}

Judging from the fact above, the writer did some actions to find probable good solutions to overcome the teachers' problems. Among other, the supervisor did coaching, guiding, discussing and socializing of standardized process as released in the educational ministry regulation number 41 year 2007 to coached teachers. Based on the regulation, a teacher should complete their teaching activities and plan administration, as follows:

$\underline{\text { Table } 1 \text { Documents of Teaching Activities and Plan Administration }}$

\begin{tabular}{|l|l|l|l|}
\hline No & \multicolumn{1}{|c|}{$\begin{array}{c}\text { Administration } \\
\text { Components }\end{array}$} & No & \multicolumn{1}{|c|}{ Administration Components } \\
\hline 1 & Yearly Program & 6 & Schedule of teaching \\
\hline 2 & Semester Program & 7 & Daily Notes/Agenda \\
\hline 3 & Teaching Syllabus & 8 & Assessment Book \\
\hline 4 & Lesson Plan & 9 & Processes of determining Learning Mastery \\
\hline 5 & Education Calendar & 10 & Student Attendance List \\
\hline
\end{tabular}

From the background of the problems above, the writer concluded the problems as follows:

What are the effective steps to be taken to overcome English teachers' teaching administration problems?

This study was aimed at improving English teachers' teaching professions particularly in administration. For Rokan Hulu regency office of educational, Youth, Sports, this was expected to become one recommendation for its future program.

For schools, teachers, and school headmasters, this writing was addressed to enhance their dedication as well as invite their willingness to find out best solution to the problems their coached teachers faced. For students, this writing was expected to be medium to make them study in a joyful learning situation. 
Gardner and Tremblay (1994) claimed that there had been orientation differences in motivation between instrumental and integrative. Integrative motivation oriented more on the wish to learn language based on a positive push to the community of language users then on the wish to get carrier, education, money, etc (as in instrumental motivation). If we tried to observe the teachers today, they tended to do things on the push of instrumental motivation like getting money or repayment. Unless they didn't do things as they were suggested to do. This is in line with what Brown (2001:75) who calls this as away from integrative motivation.

School supervisors are Civil servants who are given tasks, authority, and responsibility absolutely by authorized official to carry out academic and managerial supervision (paragraph 1, Permeneg PAN\&RB No 21/2010). In addition, their duties comprise the activities of monitoring, assessing, coaching, reporting and following up. Supervision is professional colleague assistance in the finding out of solution to overcome educational problems.

Adopted the concept of Instructional Supervision, Zepeda (2007) defines the aim of instructional supervision is:

growth and learning, ultimately leading . It means that the aims of academic supervision are to improve the teachers' competences and professionalisms.
According to the ministry of education regulation no. 16/2017, teachers' competences are ranging from pedagogical, professional, personality, and social. From those competences, the highlighted competence was teachers' pedagogical competence on how to administer their teaching activities and plans or it is called optimum professionalism (Alwasilah, 2000:30), or school qualified productivity as in Laeham dan Wexley (1992), cited in Mulyasa, (2007:135).

"...performance appraisals are crucial to the effective management of an organization's human resources, and the proper management of human resources is a critical variable affecting an organization's productivity".

\section{RESEARCH METHODOLOGY}

This study used qualitative approach. The data collection were done through the activities of pre-observation, field notes, real observation, colleague coaching or training, and documentation. The collected data were then analyzed using table of scores in the professional competence instrument. This study based its findings on the assumption that this was the best practice the writer had experienced at the time. This best practice was conducted for coached teachers for about five months started from February through June 2015 at some Senior High Schools in Rokan Hulu. The participants of this study were 20 English teachers.

\section{Procedures of the Study}


The steps of conducting academic supervision as efforts of finding solutions to overcome the teachers' teaching activities and plans problems were as follows:

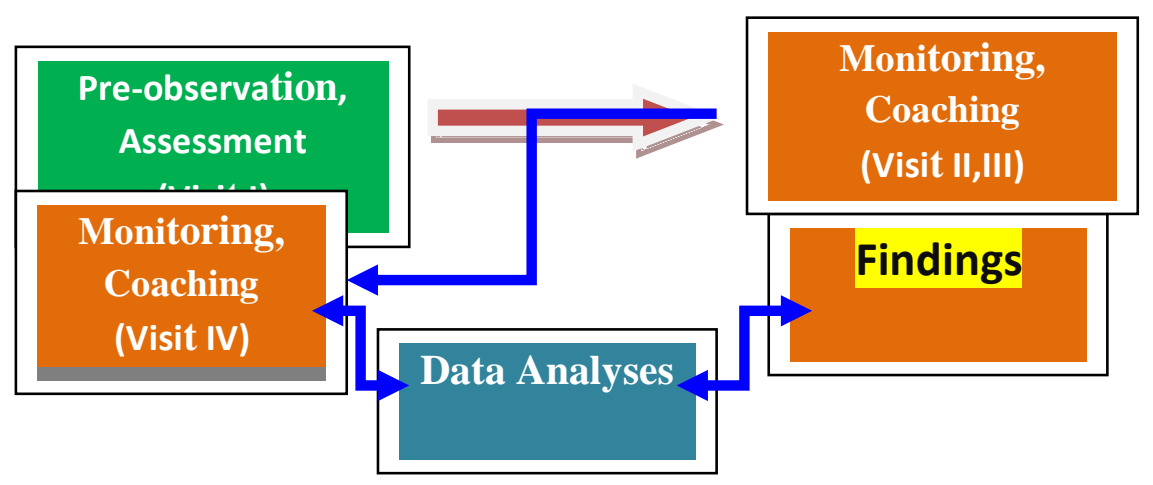

\section{RESEARCH FINDINGS}

\section{Research Finding and Discussions}

At the beginning of monitoring and pre-observation, it was found that majority of teachers did not have any administration of teaching activities and plans with them. Some teachers said, . It means that most of teachers didn't know what teaching administrations they should fulfill as teachers (particularly English teachers). The next proof about the teachers' incompetence about teaching administrations was gained after doing pre-observation. From 20 English teachers participated in this study, it was found that there were only $29 \%$ of teachers having teaching administration. The teaching administration they had was not complete yet as suggested by KTSP. Majority of the teachers did not have daily notes/agenda, the process of determining a learning mastery. The beginning data gathered were as shown in table 2 below.

Table 2 Data of Teachers' Teaching Administration Fulfillment

\begin{tabular}{|r|l|r|r|r|r|r|r|r|r|r|r|r|}
\hline No & al Names of Teacher & $Y P$ & $S P$ & $T S$ & $L P$ & $E C$ & Sot & DNA & $A B$ & $L M$ & $S A L$ & $T c S$ \\
\hline 1 & $\mathrm{MZ}$ & $\mathrm{X}$ & $\mathrm{X}$ & $\mathrm{X}$ & $\sqrt{ }$ & $\mathrm{X}$ & $\mathrm{X}$ & $\mathrm{X}$ & $\mathrm{X}$ & $\mathrm{X}$ & $\mathrm{X}$ & 1 \\
\hline 2 & DIG & $\mathrm{X}$ & $\mathrm{X}$ & $\mathrm{X}$ & $\sqrt{ }$ & $\mathrm{X}$ & $\mathrm{X}$ & $\mathrm{X}$ & $\mathrm{X}$ & $\mathrm{X}$ & $\mathrm{X}$ & 1 \\
\hline 3 & MIS & $\mathrm{X}$ & $\mathrm{X}$ & $\mathrm{X}$ & $\sqrt{ }$ & $\mathrm{X}$ & $\mathrm{X}$ & $\mathrm{X}$ & $\mathrm{X}$ & $\mathrm{X}$ & $\mathrm{X}$ & 1 \\
\hline 4 & KHAD & $\mathrm{X}$ & $\mathrm{X}$ & $\mathrm{X}$ & $\sqrt{ }$ & $\mathrm{X}$ & $\mathrm{X}$ & $\mathrm{X}$ & $\mathrm{X}$ & $\mathrm{X}$ & $\mathrm{X}$ & 1 \\
\hline
\end{tabular}




\begin{tabular}{|c|c|c|c|c|c|c|c|c|c|c|c|c|}
\hline 5 & YE & $\mathrm{X}$ & $\mathrm{X}$ & X & $\sqrt{ }$ & X & $\mathrm{X}$ & $\mathrm{X}$ & $X$ & $X$ & $\mathrm{X}$ & 1 \\
\hline 6 & KAR & $X$ & $X$ & $X$ & $\sqrt{ }$ & $X$ & $X$ & $X$ & $X$ & $X$ & $\mathrm{X}$ & 1 \\
\hline 7 & YW & $\sqrt{ }$ & $\sqrt{ }$ & $\sqrt{ }$ & $\sqrt{ }$ & $\sqrt{ }$ & $\sqrt{ }$ & $X$ & $\mathrm{X}$ & $\sqrt{ }$ & $\sqrt{ }$ & 8 \\
\hline 8 & DAR & $\sqrt{ }$ & $\sqrt{ }$ & $\sqrt{ }$ & $\sqrt{ }$ & $X$ & $\mathrm{X}$ & $\mathrm{X}$ & $\mathrm{X}$ & $X$ & $\mathrm{X}$ & 4 \\
\hline 9 & LT & $\sqrt{ }$ & $\sqrt{ }$ & $\sqrt{ }$ & $\sqrt{ }$ & $\sqrt{ }$ & $\sqrt{ }$ & $X$ & $\sqrt{ }$ & $\sqrt{ }$ & $\sqrt{ }$ & 9 \\
\hline 10 & MV & $\sqrt{ }$ & $\sqrt{ }$ & $\sqrt{ }$ & $\sqrt{ }$ & $X$ & $X$ & X & $\mathrm{X}$ & $X$ & $X$ & 4 \\
\hline 11 & $\mathrm{NE}$ & $\sqrt{ }$ & $\sqrt{ }$ & $\sqrt{ }$ & $\sqrt{ }$ & $\sqrt{ }$ & $\sqrt{ }$ & $\mathrm{X}$ & $\sqrt{ }$ & $\sqrt{ }$ & $\sqrt{ }$ & 9 \\
\hline 12 & JR & $\mathrm{X}$ & $X$ & $\mathrm{X}$ & $\sqrt{ }$ & $X$ & $\mathrm{X}$ & $\mathrm{X}$ & $\sqrt{ }$ & $X$ & $\mathrm{X}$ & 2 \\
\hline 13 & MAS & $\mathrm{X}$ & $\mathrm{X}$ & $\mathrm{X}$ & $\sqrt{ }$ & $\mathrm{X}$ & $\mathrm{X}$ & $\mathrm{X}$ & $\mathrm{X}$ & $\mathrm{X}$ & $\mathrm{X}$ & 1 \\
\hline 14 & $\mathrm{TP}$ & $\mathrm{X}$ & $\mathrm{X}$ & $\mathrm{X}$ & $\sqrt{ }$ & $\mathrm{X}$ & $\mathrm{X}$ & $\mathrm{X}$ & $\mathrm{X}$ & $\mathrm{X}$ & $\mathrm{X}$ & 1 \\
\hline 15 & HER & $\mathrm{X}$ & $\mathrm{X}$ & $\mathrm{X}$ & $\sqrt{ }$ & $\mathrm{X}$ & $\mathrm{X}$ & $\mathrm{X}$ & $\mathrm{X}$ & $\mathrm{X}$ & $\mathrm{X}$ & 1 \\
\hline 16 & KHAI & $\mathrm{X}$ & $\mathrm{X}$ & $\mathrm{X}$ & $\sqrt{ }$ & $\mathrm{X}$ & $X$ & X & $\mathrm{X}$ & $\bar{X}$ & $\mathrm{X}$ & 1 \\
\hline 17 & $\mathrm{RE}$ & $\mathrm{X}$ & $\mathrm{X}$ & $\mathrm{X}$ & $\sqrt{ }$ & $\mathrm{X}$ & $\mathrm{X}$ & $\mathrm{X}$ & $\mathrm{X}$ & $\mathrm{X}$ & $\mathrm{X}$ & 1 \\
\hline 18 & RMI & $\mathrm{X}$ & $\mathrm{X}$ & $\mathrm{X}$ & $\sqrt{ }$ & $\mathrm{X}$ & $\mathrm{X}$ & $\mathrm{X}$ & $\mathrm{X}$ & $\mathrm{X}$ & $\mathrm{X}$ & 1 \\
\hline 19 & CS & $X$ & $\mathrm{X}$ & $\mathrm{X}$ & $\sqrt{ }$ & $\mathrm{X}$ & $\mathrm{X}$ & $\mathrm{X}$ & $\mathrm{X}$ & $\mathrm{X}$ & $\mathrm{X}$ & 1 \\
\hline 20 & $\mathrm{NI}$ & $\sqrt{ }$ & $\sqrt{ }$ & $\sqrt{ }$ & $\sqrt{ }$ & $\sqrt{ }$ & $\sqrt{ }$ & X & $\sqrt{ }$ & $\sqrt{ }$ & $\sqrt{ }$ & 9 \\
\hline & & 6 & 6 & 6 & 20 & 4 & 4 & 0 & 4 & 4 & 4 & $58 / 200$ \\
\hline \multicolumn{2}{|c|}{ Percentage $(\%)$} & \multicolumn{10}{|c|}{ The amount of scores gained by a teacher/max. scoreX $100 \%$} & $29 \%$ \\
\hline
\end{tabular}

Notes:

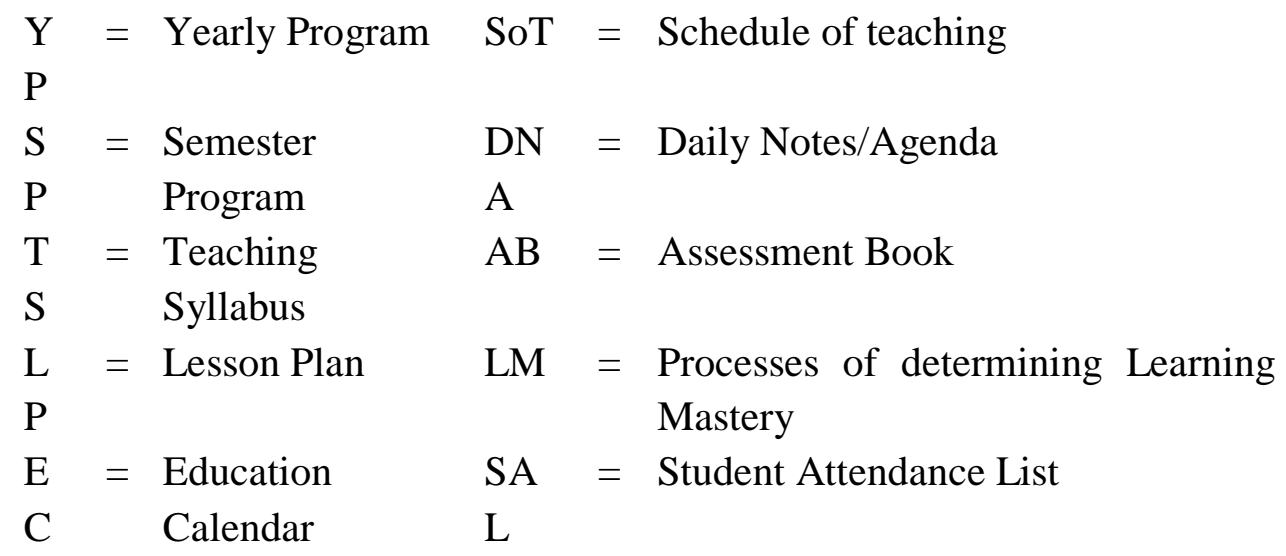




\section{$\mathrm{TcS}=$ Teacher's scores}

As shown by table 2 above, according to the regulation of ministry of educational no. 41/2007, there are 10 administration elements a teacher should prepare for their teaching activities and plans.

2. The Processes of coaching Teachers and collecting Data

On $10^{\text {th }}$ February 2015, the writer did supervision activities for coached teachers. The writer observed and interviewed them about their teaching activities and plans administration (hereafter abbreviated $T A P A)$. After a week, on February $17^{\text {th }}$, 2015, the educational ministry regulation no. 41/2007 containing TAPA was zeroxed and then distributed to coached teachers. The writer did a meeting with coached teachers discussing about TAPA at every school. In the meeting a teacher asked "what is this administration At that time the writer felt that teachers began to feel burdened. But after it was explained as prerequisites recommended by the educational ministry regulation no. 41/2007, they came to understand. The benefits of administrating TAPA are as follows:

a. By administrating and completing $T A P A$, a teacher will be assisted either in mastering the teaching materials or deepening of them. It means when a teacher was in a hurry he/she can consult his/her plan in short the problem could be minimized. b. The objective angel of the teaching materials can be controlled, so Standardized Competence and Basic Competence, together with their teaching indicator will be achieved optimally.

c. By completing TAPA, a teacher will minimize the student disappointment in studying, particularly in doing test.

d. By completing TAPA, a teacher will be able to use the time of teaching effectively.

e. By completing TAPA, a teacher will have a fair attitude to all students.

f. By completing TAPA, a teacher will be helped for controlling their students' learning progress. By having this TAPA, every activity the students did will be documented.

g. Completing TAPA will help teacher feel to select students to delegate school for a certain competition held by Rokan Hulu government.

h. Completing TAPA will help teacher map student personality, behavior, attitude, achievements, etc. i.e. students who frequently come late to school.

i. Completing TAPA will help teacher avoid anger to students, because the teachers have known the students' characteristics.

j. Completing TAPA will help teacher do enrichment and remedial, because the teachers 
have had the data about the students' achievement.

On March $10^{\text {th }}, 2015$, all coached teachers were gathered at one school. They were given training about teachers' pedagogical competence. On April $7^{\text {th }}$ through $28^{\text {th }}, 2015$, the writer visited every school where the coached teachers were teaching.

$\underline{\text { Table } 3 \text { Data of Teachers' Teaching Administration Fulfillment }}$

\begin{tabular}{|c|c|c|c|c|c|c|c|c|c|c|c|c|}
\hline No & $\begin{array}{r}\text { Initial Names of } \\
\text { Teacher }\end{array}$ & $Y P$ & $S P$ & $T S$ & $L P$ & $E C$ & Sot & $D N A$ & $A B$ & $L M$ & $S A L$ & $T c S$ \\
\hline 1 & $\mathrm{MZ}$ & $\sqrt{ }$ & $\sqrt{ }$ & $\sqrt{ }$ & $\sqrt{ }$ & $\sqrt{ }$ & $\sqrt{ }$ & $X$ & $X$ & $\mathrm{X}$ & $\mathrm{X}$ & 6 \\
\hline 2 & $\overline{D I G}$ & $\sqrt{ }$ & $\sqrt{ }$ & $\sqrt{ }$ & $\sqrt{ }$ & $\sqrt{ }$ & $\sqrt{ }$ & $\bar{X}$ & $\mathrm{X}$ & $\mathrm{X}$ & $\mathrm{X}$ & 6 \\
\hline 3 & MIS & $\sqrt{ }$ & $\sqrt{ }$ & $X$ & $\sqrt{ }$ & $X$ & $X$ & $\mathrm{X}$ & $\mathrm{X}$ & $\mathrm{X}$ & $X$ & 3 \\
\hline 4 & KHAD & $\sqrt{ }$ & $\sqrt{ }$ & $\sqrt{ }$ & $\sqrt{ }$ & $\sqrt{ }$ & $\sqrt{ }$ & $X$ & $\mathrm{X}$ & $\mathrm{X}$ & $X$ & 6 \\
\hline 5 & YE & $\sqrt{ }$ & $\sqrt{ }$ & $X$ & $\sqrt{ }$ & $X$ & $X$ & $X$ & $X$ & $X$ & $X$ & 3 \\
\hline 6 & KAR & $\sqrt{ }$ & $\sqrt{ }$ & $\sqrt{ }$ & $\sqrt{ }$ & $\sqrt{ }$ & $\sqrt{ }$ & $\mathrm{X}$ & $\mathrm{X}$ & $\mathrm{X}$ & $X$ & 6 \\
\hline 7 & YW & $\sqrt{ }$ & $\sqrt{ }$ & $\sqrt{ }$ & $\sqrt{ }$ & $\sqrt{ }$ & $\sqrt{ }$ & $X$ & $X$ & $\sqrt{ }$ & $\sqrt{ }$ & 8 \\
\hline 8 & DAR & $\sqrt{ }$ & $\sqrt{ }$ & $\sqrt{ }$ & $\sqrt{ }$ & $\mathrm{X}$ & $X$ & $X$ & $X$ & $X$ & $X$ & 4 \\
\hline 9 & LT & $\sqrt{ }$ & $\sqrt{ }$ & $\sqrt{ }$ & $\sqrt{ }$ & $\sqrt{ }$ & $\sqrt{ }$ & $X$ & $\sqrt{ }$ & $\sqrt{ }$ & $\sqrt{ }$ & 9 \\
\hline 10 & MV & $\sqrt{ }$ & $\sqrt{ }$ & $\sqrt{ }$ & $\sqrt{ }$ & $X$ & $X$ & $X$ & $X$ & $X$ & $X$ & 4 \\
\hline 11 & $\mathrm{NE}$ & $\sqrt{ }$ & $\sqrt{ }$ & $\sqrt{ }$ & $\sqrt{ }$ & $\sqrt{ }$ & $\sqrt{ }$ & $X$ & $\sqrt{ }$ & $\sqrt{ }$ & $\sqrt{ }$ & 9 \\
\hline 12 & JR & $\sqrt{ }$ & $\sqrt{ }$ & $\sqrt{ }$ & $\sqrt{ }$ & $\sqrt{ }$ & $\sqrt{ }$ & $X$ & $\sqrt{ }$ & $X$ & $X$ & 7 \\
\hline 13 & MAS & $\sqrt{ }$ & $\sqrt{ }$ & $\sqrt{ }$ & $\sqrt{ }$ & $X$ & $X$ & $X$ & $X$ & $X$ & $X$ & 4 \\
\hline 14 & $\mathrm{TP}$ & $\sqrt{ }$ & $\sqrt{ }$ & $\sqrt{ }$ & $\sqrt{ }$ & $\sqrt{ }$ & $\sqrt{ }$ & $\mathrm{X}$ & $\mathrm{X}$ & $\mathrm{X}$ & $X$ & 6 \\
\hline 15 & HER & $\sqrt{ }$ & $\sqrt{ }$ & $\sqrt{ }$ & $\sqrt{ }$ & $\sqrt{ }$ & $\sqrt{ }$ & $X$ & $X$ & $X$ & $X$ & 6 \\
\hline 16 & KHAI & $\sqrt{ }$ & $\sqrt{ }$ & $\sqrt{ }$ & $\sqrt{ }$ & $X$ & $X$ & $X$ & $X$ & $X$ & $X$ & 4 \\
\hline 17 & $\mathrm{RE}$ & $\sqrt{ }$ & $\sqrt{ }$ & $X$ & $\sqrt{ }$ & $X$ & $X$ & $X$ & $X$ & $X$ & $X$ & 3 \\
\hline 18 & RMI & $\sqrt{ }$ & $\sqrt{ }$ & $\sqrt{ }$ & $\sqrt{ }$ & $X$ & $\mathrm{X}$ & $\mathrm{X}$ & $\mathrm{X}$ & $\mathrm{X}$ & $X$ & 4 \\
\hline 19 & CS & $\sqrt{ }$ & $\sqrt{ }$ & $X$ & $\sqrt{ }$ & $X$ & $\mathrm{X}$ & $X$ & $X$ & $X$ & $X$ & 3 \\
\hline
\end{tabular}




\begin{tabular}{|l|c|r|r|r|r|r|r|r|r|r|r|r|}
\hline 20 & NI & $\sqrt{ }$ & $\sqrt{ }$ & $\sqrt{ }$ & $\sqrt{ }$ & $\sqrt{ }$ & $\sqrt{ }$ & X & $\sqrt{ }$ & $\sqrt{ }$ & $\sqrt{ }$ & 9 \\
\hline & 6 & 6 & 6 & 20 & 4 & 4 & 0 & 4 & 4 & 4 & 200 \\
\hline
\end{tabular}

Notes:

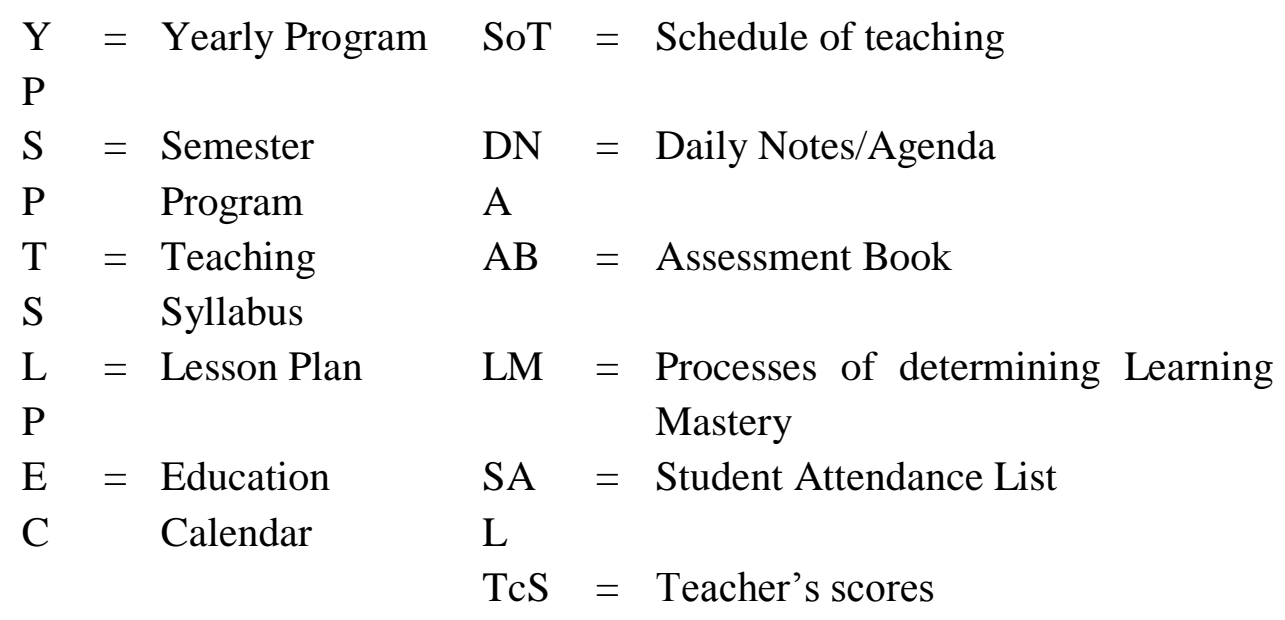

Table 3 above shows that $55 \%$ of teachers had fulfilled their teaching administration.
On May $5^{\text {th }}, 2015$, the activity of coaching, supervising, and guiding were carried out to all participants.

Table 4 Data of Teachers' Teaching Administration Fulfillment

\begin{tabular}{|c|c|c|c|c|c|c|c|c|c|c|c|c|}
\hline No & total submission & $Y P$ & $S P$ & $T S$ & $L P$ & $E C$ & Sot & DNA & $A B$ & $L M$ & $S A L$ & $T c S$ \\
\hline 1 & 13 & $\sqrt{ }$ & $\sqrt{ }$ & $\sqrt{ }$ & $\sqrt{ }$ & $\sqrt{ }$ & $\sqrt{ }$ & $\mathrm{X}$ & $\mathrm{X}$ & $\mathrm{X}$ & $\sqrt{ }$ & $13 / 10$ \\
\hline & & 1 & 1 & 1 & 1 & 1 & 1 & 0 & 0 & 0 & 1 & \\
\hline & & \multicolumn{10}{|c|}{$7 / 10 \times 100 \%=70 \%$ Administration components } & \\
\hline \multicolumn{2}{|c|}{ Percentage (\%) } & & & & & & & & & & & $65 \%$ \\
\hline
\end{tabular}

The table above shows that $65 \%$ teachers had fulfilled $70 \%$ of their teaching administration. It means teachers had enhanced their competence in managing their teaching administration.
On June $5^{\text {th }}$, 2015, a month after, $87 \%$ teachers had finished their teaching activities and plan administration (TAPA) as shown by Table 5 below. 
Table 5 Data of Teachers' Teaching Administration Fulfillment

\begin{tabular}{|c|c|c|c|c|c|c|c|c|c|c|c|c|}
\hline No & $\begin{array}{r}\text { Initial Names of } \\
\text { Teacher }\end{array}$ & $Y P$ & $S P$ & $T S$ & $L P$ & $E C$ & Sot & $D N A$ & $A B$ & $L M$ & $S A L$ & $T c S$ \\
\hline 1 & $\mathrm{MZ}$ & $\sqrt{ }$ & $\sqrt{ }$ & $\sqrt{ }$ & $\sqrt{ }$ & $\sqrt{ }$ & $\sqrt{ }$ & $\mathrm{X}$ & $\sqrt{ }$ & $\mathrm{X}$ & $\sqrt{ }$ & 8 \\
\hline 2 & DIG & $\sqrt{ }$ & $\sqrt{ }$ & $\sqrt{ }$ & $\sqrt{ }$ & $\sqrt{ }$ & $\sqrt{ }$ & $X$ & $\sqrt{ }$ & $X$ & $\sqrt{ }$ & 8 \\
\hline 3 & MIS & $\sqrt{ }$ & $\sqrt{ }$ & $\sqrt{ }$ & $\sqrt{ }$ & $\sqrt{ }$ & $\sqrt{ }$ & $X$ & $\sqrt{ }$ & $X$ & $\sqrt{ }$ & 8 \\
\hline 4 & KHAD & $\sqrt{ }$ & $\sqrt{ }$ & $\sqrt{ }$ & $\sqrt{ }$ & $\sqrt{ }$ & $\sqrt{ }$ & $\sqrt{ }$ & $\sqrt{ }$ & $\sqrt{ }$ & $\sqrt{ }$ & 10 \\
\hline 5 & YE & $\sqrt{ }$ & $\sqrt{ }$ & $\sqrt{ }$ & $\sqrt{ }$ & $\sqrt{ }$ & $\sqrt{ }$ & $\sqrt{ }$ & $\sqrt{ }$ & $\sqrt{ }$ & $\sqrt{ }$ & 10 \\
\hline 6 & KAR & $\sqrt{ }$ & $\sqrt{ }$ & $\sqrt{ }$ & $\sqrt{ }$ & $\sqrt{ }$ & $\sqrt{ }$ & $\sqrt{ }$ & $\sqrt{ }$ & $\sqrt{ }$ & $\sqrt{ }$ & 10 \\
\hline 7 & YW & $\sqrt{ }$ & $\sqrt{ }$ & $\sqrt{ }$ & $\sqrt{ }$ & $\sqrt{ }$ & $\sqrt{ }$ & $\sqrt{ }$ & $\sqrt{ }$ & $\sqrt{ }$ & $\sqrt{ }$ & 10 \\
\hline 8 & $\overline{\text { DAR }}$ & $\sqrt{ }$ & $\sqrt{ }$ & $\sqrt{ }$ & $\sqrt{ }$ & $\sqrt{ }$ & $\sqrt{ }$ & $\mathrm{X}$ & $\sqrt{ }$ & $X$ & $\sqrt{ }$ & 8 \\
\hline 9 & LT & $\sqrt{ }$ & $\sqrt{ }$ & $\sqrt{ }$ & $\sqrt{ }$ & $\sqrt{ }$ & $\sqrt{ }$ & $\sqrt{ }$ & $\sqrt{ }$ & $\sqrt{ }$ & $\sqrt{ }$ & 10 \\
\hline 10 & MV & $\sqrt{ }$ & $\sqrt{ }$ & $\sqrt{ }$ & $\sqrt{ }$ & $\sqrt{ }$ & $\sqrt{ }$ & $X$ & $\sqrt{ }$ & $X$ & $\sqrt{ }$ & 8 \\
\hline 11 & $\mathrm{NE}$ & $\sqrt{ }$ & $\sqrt{ }$ & $\sqrt{ }$ & $\sqrt{ }$ & $\sqrt{ }$ & $\sqrt{ }$ & $\sqrt{ }$ & $\sqrt{ }$ & $\sqrt{ }$ & $\sqrt{ }$ & 10 \\
\hline 12 & JR & $\sqrt{ }$ & $\sqrt{ }$ & $\sqrt{ }$ & $\sqrt{ }$ & $\sqrt{ }$ & $\sqrt{ }$ & $\mathrm{X}$ & $\sqrt{ }$ & $X$ & $\sqrt{ }$ & 8 \\
\hline 13 & MAS & $\sqrt{ }$ & $\sqrt{ }$ & $\sqrt{ }$ & $\sqrt{ }$ & $\sqrt{ }$ & $\sqrt{ }$ & $\mathrm{X}$ & $\sqrt{ }$ & $\mathrm{X}$ & $\sqrt{ }$ & 8 \\
\hline 14 & $\mathrm{TP}$ & $\sqrt{ }$ & $\sqrt{ }$ & $\sqrt{ }$ & $\sqrt{ }$ & $\sqrt{ }$ & $\sqrt{ }$ & $\sqrt{ }$ & $\sqrt{ }$ & $\sqrt{ }$ & $\sqrt{ }$ & 10 \\
\hline 15 & HER & $\sqrt{ }$ & $\sqrt{ }$ & $\sqrt{ }$ & $\sqrt{ }$ & $\sqrt{ }$ & $\sqrt{ }$ & $\sqrt{ }$ & $\sqrt{ }$ & $\sqrt{ }$ & $\sqrt{ }$ & 10 \\
\hline 16 & KHAI & $\sqrt{ }$ & $\sqrt{ }$ & $\sqrt{ }$ & $\sqrt{ }$ & $\sqrt{ }$ & $\sqrt{ }$ & $\sqrt{ }$ & $\sqrt{ }$ & $\sqrt{ }$ & $\sqrt{ }$ & 10 \\
\hline 17 & $\mathrm{RE}$ & $\sqrt{ }$ & $\sqrt{ }$ & $\sqrt{ }$ & $\sqrt{ }$ & $\sqrt{ }$ & $\sqrt{ }$ & $X$ & $\sqrt{ }$ & $\sqrt{ }$ & $\sqrt{ }$ & 9 \\
\hline 18 & RMI & $\sqrt{ }$ & $\sqrt{ }$ & $\sqrt{ }$ & $\sqrt{ }$ & $\sqrt{ }$ & $\sqrt{ }$ & $\sqrt{ }$ & $X$ & $X$ & $X$ & 7 \\
\hline 19 & $\mathrm{CS}$ & $\sqrt{ }$ & $\sqrt{ }$ & $\sqrt{ }$ & $\sqrt{ }$ & $\sqrt{ }$ & $\mathrm{X}$ & $\mathrm{X}$ & $\mathrm{X}$ & $\mathrm{X}$ & $\mathrm{X}$ & 5 \\
\hline 20 & $\mathrm{NI}$ & $\sqrt{ }$ & $\sqrt{ }$ & $\sqrt{ }$ & $\sqrt{ }$ & $\sqrt{ }$ & $\sqrt{ }$ & $\sqrt{ }$ & $\sqrt{ }$ & $\sqrt{ }$ & $\sqrt{ }$ & 10 \\
\hline & & 6 & 6 & 6 & 20 & 4 & 4 & 0 & 4 & 4 & 4 & $74 / 200$ \\
\hline & Percentage (\%) & \multicolumn{10}{|c|}{ The amount of scores gained by a teacher/max. scoreX $100 \%$} & $87 \%$ \\
\hline
\end{tabular}

Notes: 


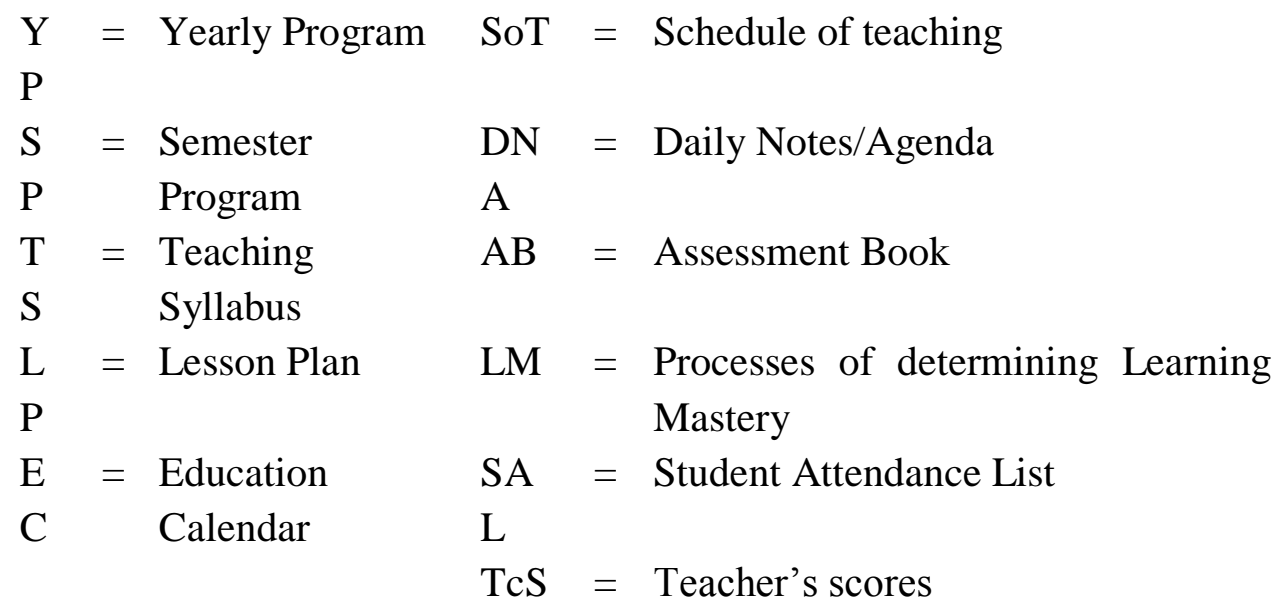

The table indicates that there is a significant improvement gained by teachers or participants after following activities of supervising, coaching, and guiding from supervisor.

This is the best and first experience I had as a school supervisor in supervising teachers, in this case English teachers.

\section{CONCLUSION AND SUGGESTION}

\section{Conclusion}

Although not $100 \%$ of teachers had teaching activities and plans administration document well, the writer felt grateful to Allah the almighty God for the first experience as school supervisor. As stated in research findings of the study, it is effective to improve the teachers' quality of teachers' teaching administration plans by doing academic supervising, coaching, and guiding. The improvement progress was ranging from $29 \%$ to $87 \%$ (beginning to end of the research activities). In addition, to improve the teachers' competence and professionalism effectively and optimally in managing their teaching administration, we also have to do friendly shares and discussion with coached teachers; in short, we have to keep in touch one another.

\section{Suggestion}

Based on the research findings, school supervisors are recommended to do similar activities to prove the truth of them. For teachers, particularly English teachers, it is suggested that they have a serious will to change their mind set in order to improve their competence and professionalism. Fulfilling teaching administration is a must for us to do as suggested by KTSP. Finally, the writer expects that this writing will contribute beneficial values for the sake of improving the quality of education, particularly in Kabupaten Rokan Hulu.

\section{REFERENCES}

Alwasilah, A. Chaedar. 2000. Perspektif Pendidikan Bahasa Inggris di Indonesia. Bandung: Adira.

Brown, H. Douglas. 2001. Teaching by Principles $\left(2^{\text {nd }}\right)$. White Plains NY: AddisonWesley Longman, Inc. 
Depdikbud. 2003. Standar kompetensi guru sekolah menengah. : Jakarta: Direktorat Jenderal Pendidikan Dasar Dan Menengah Direktorat Tenaga Kependidikan.

Basuki, Wibawa. 2003. Penelitian tindakan kelas. Jakarta : Departemen Pendidikan Nasional, Direktorat Pendidikan Dasar dan Menengah, Direktorat Tenaga Kependidikan.

BSNP. (2007). Peraturan Menteri Pendidikan Nasional Republik Indonesia Nomor 16 Tahun 2007 Tentang Standar Kualifikasi Akademik dan Kompetensi Guru. Jakarta : BSNP.

Combs. Arthur. W. 1984. The Profesional Education of Teachers. Boston: Allin and Bacon, Inc. Boston.

Depdiknas. 2007. Pedoman bantuan langsung (block grant) pelaksanaan penelitian tidakan bagi pengawas sekolah sma/smk. Jakarta: Direktoral Tenaga Kependidikan Direktoral Jendral Peningkatan Mutu Pendidikan Dasar dan Menengah Direktorat Tenaga Kependidikan.

Depdiknas. 2005. Undang-undang republik Indonesia tentang guru dan dosen tahun 2005. Jakarta: Cemerlang Jakarta.

Depdikbud. 1994. Kelompok guru mata pelajaran pendidikan pancasila dan kewarganegaraan. Jakarta : Departemen Pendidikan dan
Kebudayaan Direktorat Jendral Pendidikan Dasar dan Menengah.

Kemdikbud. 2015. Panitia Penulisan "Best Practice" Pengawas. Jakarta: Subdit Program dan Evaluasi Direktorat Pembinaan PTK Pendidikan Menengah Direktorat JenderalPendidikan Menengah.

Kemdikbud. 2015. Standar Nasional Pendidikan. Standar Proses. Jakarta: BSNP.

Mulyasa, E. DR. 2007. Menjadi Kepala Sekolah Profesional. Bandung: PT Rosda Karya

Kemen PAN RB. 2010. Jabatan Fungsional Pengawas Sekolah Dan Angka Kreditnya. Jakarta: Kemenpan RB.

Zepeda (2007) dalam Hamdani. 2015. Slide Modul. Diklat Calon Pengawas angkatan 26. Padang: Badan Diklat Padang Besi. 